\title{
EXPERIMENTAL STUDIES OF THE INFLUENCE OF WAVES ON THE BREAKWATER OF A PARTIAL VERTICAL PROFILE
}

\author{
Synytsia R.V., Assistant, \\ sinitsa_roma@ukr.net, ORCID: 0000-0001-6796-4785 \\ Odessa State Academy of Civil Engineering and Architecture \\ Didrichson str, 4, Odessa, 65029, Ukraine
}

\begin{abstract}
The article is devoted to the issues of physical experimental researches connected with the determination of the parameters of wave quenching when overflowing them through the superstructure of enclosing hydraulic structures (ENS) of incomplete vertical profile. The research was conducted in the hydrowave laboratory of the Department of Hydraulic Engineering of the Odessa State Academy of Civil Engineering and Architecture. The article presents partial results of experiments performed on ENS of incomplete vertical profile. The models were made on a geometric scale and were subjected to wave effects similar to the conditions of the natural section of the coast of the Odessa Bay in compliance with the criteria of similarity.

The construction of new structures of enclosing hydraulic structures requires careful primary experimental research. These researches mostly often carried out on physical models in specialized hydrowave laboratories, allow to get rid of risks of financial losses at the wrong choice of types and elements of the designed objects. The carried out researches allow estimating with a high degree of reliability, according to scale conditions, physics of the processes proceeding on models which will also be observed at the operation of real construction. The physics of the process of hydrodynamic impact on hydraulic structures is often difficult to describe only with the help of a mathematical model, which confirms the high degree of importance of physical experiments.

The progress of technical science largely depends on the ability to make more accurate measurements. High-precision measuring equipment was used in laboratory tests.

This paper describes the method of conducting experiments that were performed on one physical model, under three different conditions of the location of the superstructure relative to the quiet level, as well as different values of the initial wave heights.

The use of structures of incomplete vertical profile, in order to protect the waters of seaports, as well as elements of the coastal infrastructure of maritime cities will increase economic attractiveness by reducing financial costs, thanks to the reduction of the topside of the enclosing structures.
\end{abstract}

Keywords: hydrowave tray, physical modeling, enclosing hydraulic structure of incomplete vertical profile.

Introduction. In the engineering practice of construction of enclosing and shore protection structures, structures of incomplete vertical profile are used, through the crest of which a partial overflow of waves with a further change of their main parameters is allowed. However, in the normative documents of many countries on the design of enclosing hydraulic structures, there are no practical recommendations to determine the amount of wave damping by structures of this type.

Many specialists have studied these issues, the results of which have been published in the extensive literature [1-5]. In practice, the allowable wave heights in the protected waters of seaports are regulated by the parameters of the displacement of the settlement vessel, as well as the method of setting it to the wavefront. These norms establish the requirements for the possibility of mooring operations and the provision at the time of contact of the vessel with the jack devices of berths, the normal components of their approach speed. Permissible wave heights expected on the protected areas of urban infrastructure are regulated by the parameters of preservation of seashores and beach material, prevention of flooding of coastal areas due to the impact of storms of rare recurrence.

The progress of technical science largely depends on the ability to make more accurate measurements. High-precision measuring equipment was used in laboratory tests. 
This paper describes the method of conducting experiments that were performed on one physical model, under three different conditions of the location of the superstructure of the enclosure in relation to the calm water level, as well as different values of the initial wave heights.

Analysis of recent research. The literature review showed that studies of the issues of wave damping, construction of enclosing structures of incomplete vertical profile, were carried out both in the Soviet Union and abroad. However, currently, there are no practical recommendations in the regulations that could be used in engineering practice.

Experimental data of laboratory researches at the frontal approach of waves, were analyzed in discussion O.Yu. Birskoy [2]. In order to determine the damping coefficients of the waves, it was recommended to use formula (1):

$$
k_{B \Gamma}=\frac{h-h_{0}}{h}=\sqrt{\frac{h}{\lambda}} \cdot\left(0.23 \frac{B}{h}+2.3 \frac{\Delta H}{h}+1.6\right),
$$

where: $h$ - source wave height $(\mathrm{m})$;

$h_{0}$ - residual wave height between the breakwater and the shore $(\mathrm{m})$;

$\lambda$ - source wavelength (m);

$\Delta H$ - elevation of the top of the structure relative to the calculated water level $(\mathrm{m}) ;$

$B$ - ridge width (m).

After analyzing and comparing the results of similar experimental studies of wave damping parameters published by various authors (Seeling, 1980; Allsop, 1983; Daemrich and Kahle, 1985; Powel and Allsop, 1985; van der Meer, 1988; Daemen, 1991), d ' Angremond [3] it was proposed to apply the following dependence (2) to determine the parameters of wave transformation by coweapons of an incomplete vertical profile:

$$
k_{t}=-0.4 \frac{R_{s}}{H_{i}}+0.80 \cdot\left(\frac{B}{H_{i}}\right)^{-0.31} \cdot\left(1-e^{-0.5 \zeta}\right),
$$

where: $R_{s}$ - elevation of the top of the structure relative to the calculated water level $(\mathrm{m})$;

$H_{i}$ - source wave height $(\mathrm{m})$;

$B$ - ridge width (m);

$\zeta$ - coefficient taking into account the influence of the location of the breakwater in relation to the wave profile, determined by the formula (3):

$$
\zeta=\frac{\tan \alpha}{\sqrt{H_{i} / L_{0}}}
$$

where: $\alpha$ - angle of propagation of the wave beam with respect to the longitudinal axis of the structure.

After processing numerous experimental data on wave effects on ENS of incomplete vertical profile, Briganti and others [4] in 2003 proposed an empirical dependence (4):

$$
k_{t}=-0.35 \cdot \frac{R_{s}}{H_{i}}+0.51 \cdot\left(\frac{B}{H_{i}}\right)^{-0.65} \cdot\left(1-e^{-0.41 \zeta}\right),
$$

where: $h_{s}$ - elevation of the top of the structure relative to the calculated water level $(\mathrm{m})$;

$H_{i}$ - source wave height $(\mathrm{m})$;

$B$ - ridge width (m).

The aim of the work was to review the existing engineering techniques, both domestic and foreign, related to the determination of wave damping parameters by the structures of enclosing structures of incomplete vertical profile. Carrying out a physical experiment on a model of the construction of an incomplete vertical profile in order to determine the parameters of wave damping. The purpose of further research was to conduct a comparative analysis of the obtained data of physical experiments with published methods of various authors. These studies were conducted in connection with the lack of practical engineering techniques in the regulations of Ukraine and other countries.

Bulletin of Odessa State Academy of Civil Engineering and Architecture, 2020, no. 80, page 93-102 
Research methods. In the practice of the construction of enclosing hydraulic structures, structures of incomplete vertical profile are sometimes used (Fig. 1), through the superstructure of which the overflow of waves with the further transformation (change of their main parameters) is allowed. Depending on the conditions of their use, these structures can be exposed to both standing and breaking waves. However, in the normative documents of Ukraine and many other countries, there are no practical recommendations to determine the amount of wave damping by structures of this type.

Permissible parameters of waves expected in the protected waters of the coastal infrastructure of maritime cities are regulated by the parameters of preservation of shores and beach material, as well as the prevention of flooding of coastal areas due to wave effects of storms of rare recurrence. In cases of protection against sea waves, it is recommended to take $1.2(\mathrm{~m})$ permissible wave heights with security of $5 \%$ in the storm system. These conditions are set based on the implementation of mooring operations, as well as ensuring at the time of contact of vessels with berths, the normal component of their approach speed.

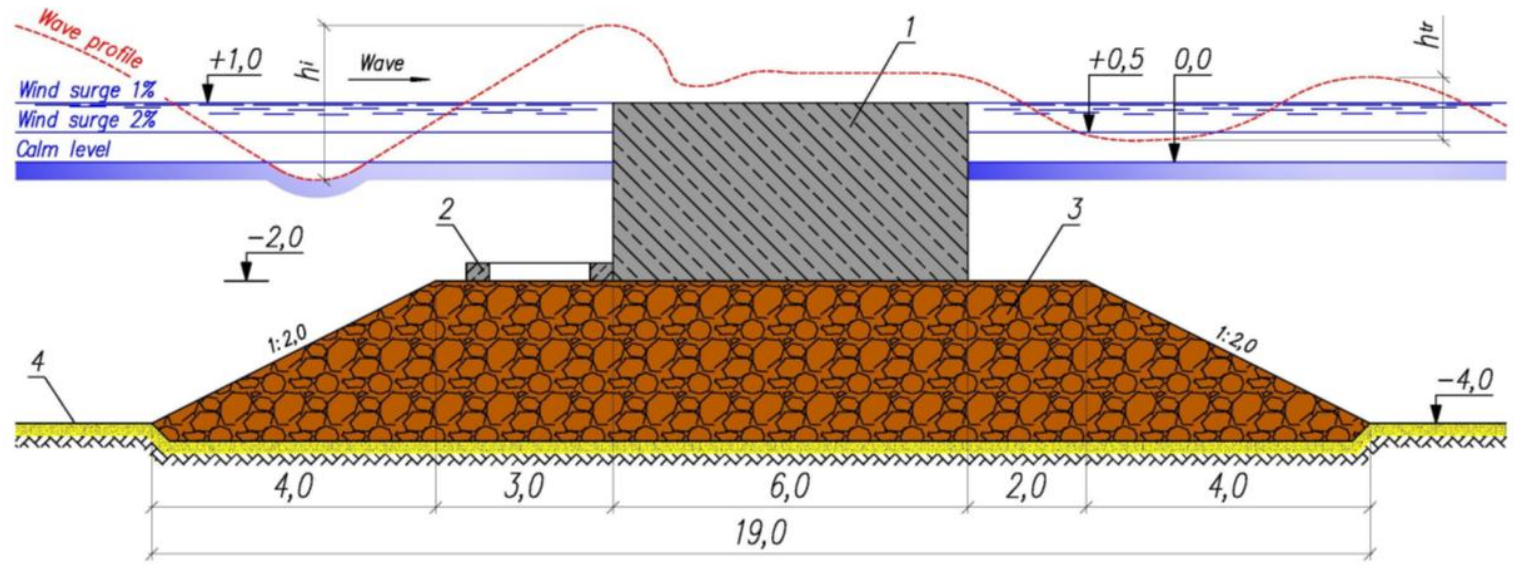

Fig. 1. Cross section of the construction of a breakwater of an incomplete vertical profile:

1 - concrete mass; 2 - pregnant massif (slotted plate); 3 - stone bed

As an example, the project «Design justification and design of structures of hydraulic structures for protection against flooding by sea waves of the plant's territory at the address: Odessa, st. Chernomorskogo Cossachestva, 72» [6]. In the project, the creation of an enclosing structure of an incomplete vertical profile, located at a distance of $200 \mathrm{~m}$ from the coastline, was considered. The construction was supposed to be located at a depth $d=4.0(\mathrm{~m})$, due to the wind which can reach $d=5.0(\mathrm{~m})$. Having built the refraction rays, the values of the basic wave parameters of $1 \%$ coverage were established in accordance with the requirements of the standards at the location of the designed structure. Wave height $1 \%$ security at depth $d=4.0(\mathrm{~m})$ will make $h=2.4(\mathrm{~m})$, and the average length will be equal $\lambda=24.5(\mathrm{~m})$. With a wave surge of $1 \%$ security in the Odessa Gulf, the wave height will be $h=2.55(\mathrm{~m})$, and the length is the average wavelength $\lambda=30.0(\mathrm{~m})$. In accordance with the calculations, it was found that in order to avoid flooding of the protected area of the plant, the permissible wave height should not exceed $h=1.5(\mathrm{~m})$.

Research results. The author of the article conducted experimental studies in the hydrowave tray of the laboratory of the Department of «Hydraulic Engineering» Odessa State Academy of Civil Engineering and Architecture. In order to conduct research in the hydrowave tray, an experimental physical model was created, which is presented in Fig. 2. The model was exposed to large-scale effects of the calculated parameters of the waves, at three different calculated elevations of calm water levels. 


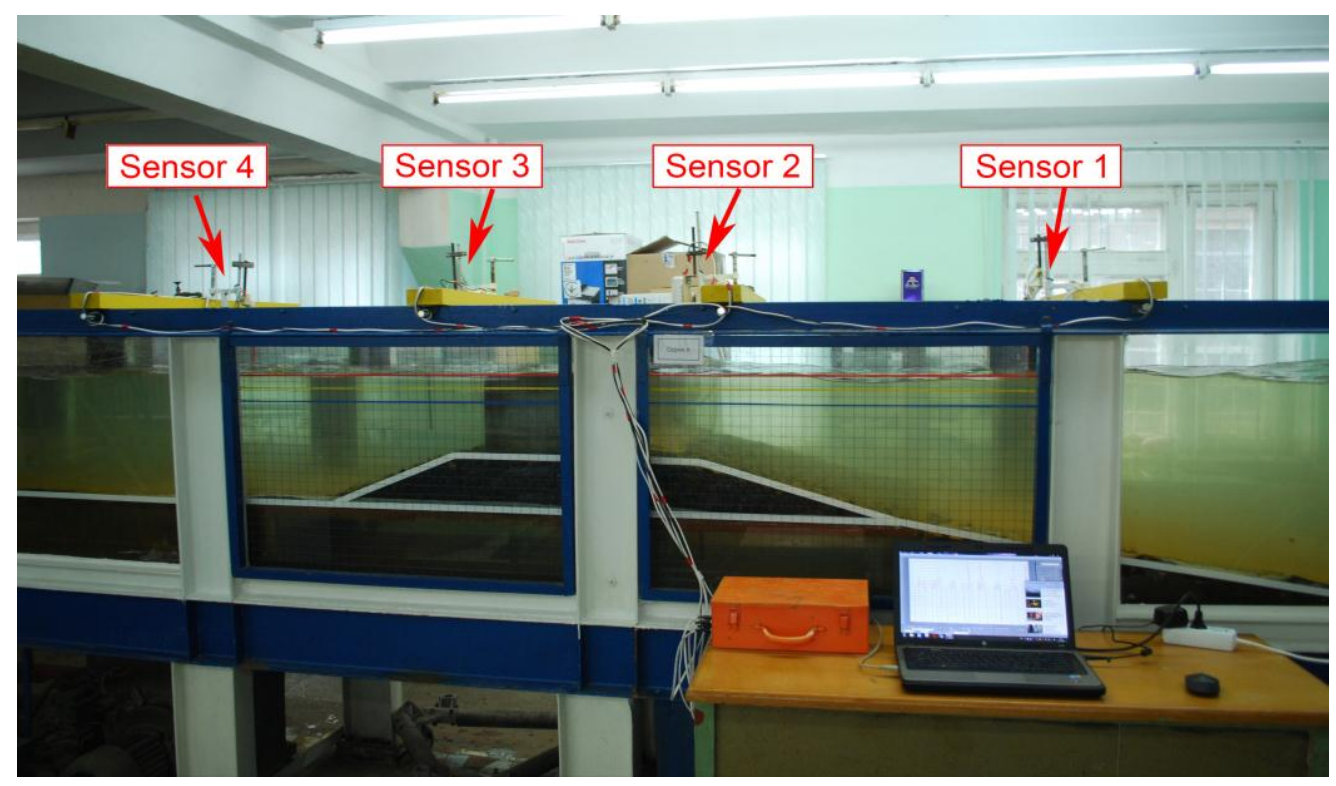

Fig. 2. Model of an incomplete vertical enclosure

For the purpose of the most exact and reliable technique of an estimation of work of a protective construction of an incomplete vertical profile, and also a possibility of comparison of the received experimental results with results of the experimental researches carried out earlier, geometrical parameters of a construction (fig. 1) were accepted similar in scale to the size described in the literary source [2].

The experimental tray is a box of rectangular cross-section, the length of which was $-15.0(\mathrm{~m})$, and width $-1.0(\mathrm{~m})$. The height of the board in the tray was equal to $1.0(\mathrm{~m})$. For the convenience of work with the model, the tray is lifted over a floor of the room, on the height of $1.0(\mathrm{~m})$, the wave tray is equipped with glass sidewalls. At one end of the tray a waveform of the panel type, designed for the formation of waves is placed, and on the opposite side of the tray is a wave damper.

The aim of the study was to determine the parameters of the waves in front of OGTS incomplete vertical profile at a distance of two wavelengths (Sensor 1), measuring the parameters of the waves formed above the stone bed directly in front of the concrete mass of the structure (Sensor 2), just behind the vertical barrier structures (Sensor 3), as well as in the most protected area (Sensor 4). The location of the measuring sensors in the hydrowave tray is shown in Fig. 2.

In the formation of surface waves and their interaction with the barrier, the most important and prevailing factor in the ongoing processes are gravitational forces - gravitational forces, which is why these waves are called gravitational. The influence of friction forces, capillarity, and elasticity on the processes taking place in these conditions is almost imperceptible. Thus, for example, in accordance with the literature [7], the effect of surface tension on the formation of gravitational waves at the speed of propagation of the waveform can be estimated to be approximately less than $1 \%$ of the action of gravity. Which gives the right to study the models of the interaction of gravitational waves with the enclosure to recalculate the obtained experimental results in kind in accordance with the law of mechanical similarity and, in particular, the law of gravitational similarity [8, 9].

Before the start of physical experiments, methodological experiments were performed, which consisted of selecting a range of values of wave parameters. The heights and periods of the waves were determined based on the heights of the values that were determined when approaching the projected structure when performing research work [1]. Subsequently, the measuring system was debugged. The device of measuring sensors is presented in the publication [10]. In accordance with [11], a research plan was developed, the partial results of which are presented in Table 1-3, and the graphical construction is presented in Fig. 3-5. The results of the conducted physical experiments on the model of the enclosing structure of incomplete vertical profile at the width of the superstructure and three different values of the location of the superstructure in relation to the calm water level are presented.

Bulletin of Odessa State Academy of Civil Engineering and Architecture, 2020, no. 80, page 93-102 
Table 1 - The results of experiments with the width of the concrete mass $b=6.0(\mathrm{~m})$ and elevation $\Delta \mathrm{H}=1.0(\mathrm{~m})$

\begin{tabular}{|c|c|c|c|c|c|c|c|c|}
\hline № & $\begin{array}{c}\text { Sensor } \\
\text { №1 }(\mathrm{m})\end{array}$ & $\begin{array}{c}\text { Sensor } \\
\text { №2 }(\mathrm{m})\end{array}$ & $\begin{array}{c}\text { Sensor } \\
\text { №3 }(\mathrm{m})\end{array}$ & $\begin{array}{c}\text { Sensor } \\
\text { №4 }(\mathrm{m})\end{array}$ & K, \% & $\begin{array}{c}\text { Formula } \\
\text { O.Yu. Birskoy }\end{array}$ & $\begin{array}{c}\text { Formula } \\
\text { d'Angremond }\end{array}$ & $\begin{array}{c}\text { Formula } \\
\text { Briganti }\end{array}$ \\
\hline 1 & 2 & 3 & 4 & 5 & 6 & 7 & 8 & 9 \\
\hline 1 & 2.82 & 1.64 & 0.67 & 0.62 & 76.24 & 0.40 & 0.38 & 0.11 \\
\hline 2 & 2.71 & 1.54 & 0.40 & 0.62 & 85.24 & 0.35 & 0.36 & 0.10 \\
\hline 3 & 2.66 & 1.52 & 0.40 & 0.58 & 84.96 & 0.32 & 0.36 & 0.09 \\
\hline 4 & 2.55 & 1.50 & 0.53 & 0.54 & 79.22 & 0.26 & 0.34 & 0.08 \\
\hline 5 & 2.53 & 1.44 & 0.53 & 0.54 & 79.05 & 0.25 & 0.34 & 0.08 \\
\hline 6 & 2,23 & 1.30 & 0.53 & 0.46 & 76.23 & 0.09 & 0,30 & 0.04 \\
\hline 7 & 2.07 & 1.20 & 0.40 & 0.44 & 80.68 & 0.01 & 0,28 & 0.02 \\
\hline 8 & 1.86 & 1.06 & 0.53 & 0.46 & 71.51 & -0.10 & 0.24 & -0.01 \\
\hline 9 & 1.62 & 0.96 & 0.27 & 0.32 & 83.33 & -0.23 & 0.19 & -0.05 \\
\hline 10 & 1.60 & 0.90 & 0.27 & 0.32 & 83.13 & -0.24 & 0.18 & -0.06 \\
\hline 11 & 1.49 & 0.92 & 0.67 & 0.30 & 55.03 & -0.30 & 0.16 & -0.08 \\
\hline 12 & 1.46 & 0.92 & 0.27 & 0.32 & 81.51 & -0.31 & 0,15 & -0.09 \\
\hline 13 & 1.44 & 0.90 & 0.27 & 0.30 & 81.25 & -0.32 & 0,14 & -0.09 \\
\hline 14 & 1.38 & 0.82 & 0.27 & 0.28 & 80.43 & -0.36 & 0.12 & -0.11 \\
\hline 15 & 1.28 & 0.80 & 0.27 & 0.26 & 78.91 & -0.41 & 0.09 & -0.13 \\
\hline 16 & 1.17 & 0.78 & 0.40 & 0.24 & 65.81 & -0.47 & 0.05 & -0.17 \\
\hline 17 & 1.09 & 0.74 & 0.27 & 0.22 & 75.23 & -0.51 & 0.02 & -0.19 \\
\hline 18 & 1.06 & 0.70 & 0.53 & 0.24 & 50.00 & -0.53 & 0.00 & -0.21 \\
\hline 19 & 0.85 & 0.64 & 0.27 & 0.20 & 68.24 & -0.64 & -0.11 & -0.30 \\
\hline 20 & 0.69 & 0.60 & 0.40 & 0.18 & 42.03 & -0.72 & -0.25 & -0.41 \\
\hline
\end{tabular}

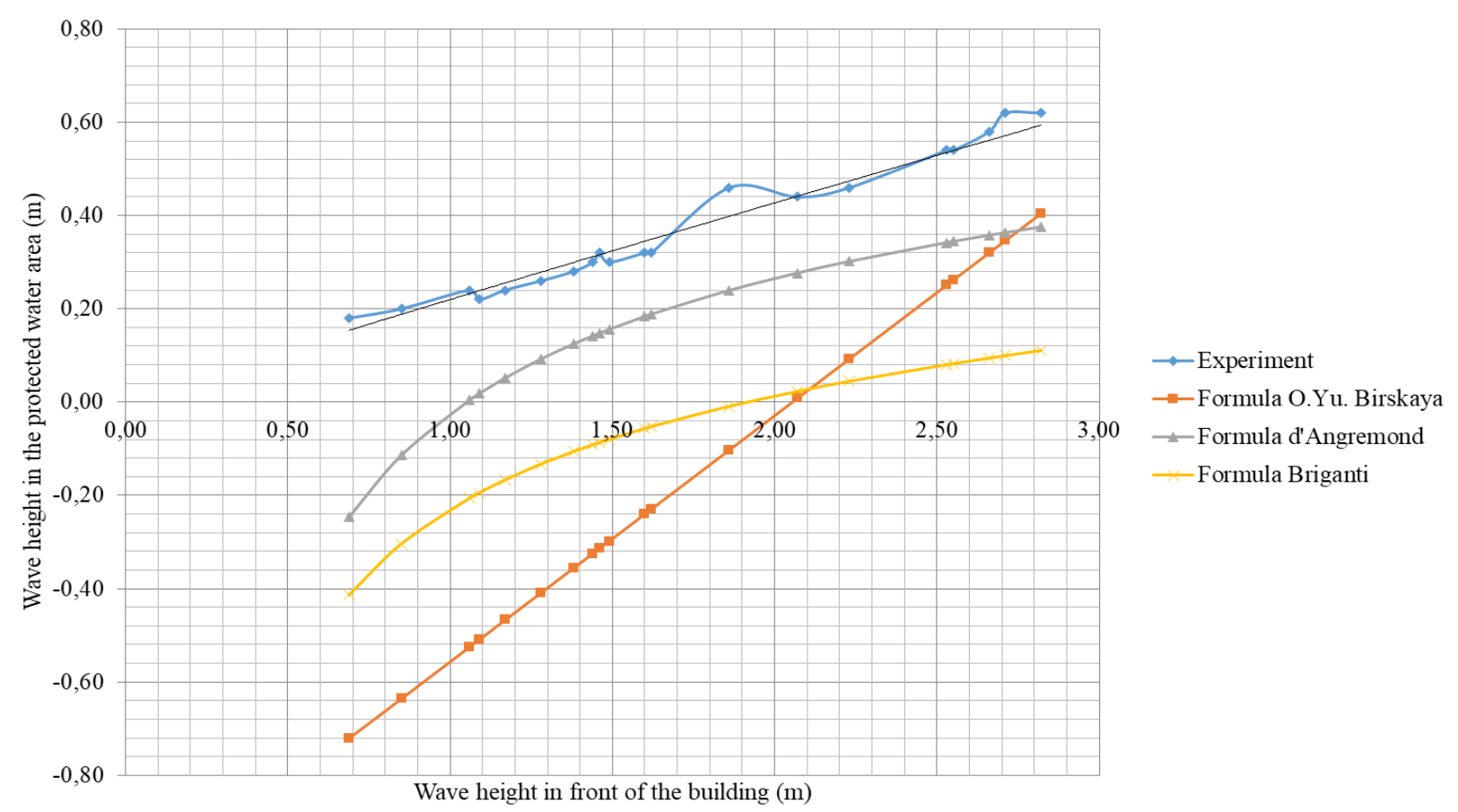

Fig. 3. Parameters of wave transformation at the width of the concrete massif $b=6.0(\mathrm{~m})$ and elevation $\Delta \mathrm{H}=1.0(\mathrm{~m})$ 
Table 2 - The results of experiments with the width of the concrete mass $b=6.0(\mathrm{~m})$ and elevation $\Delta \mathrm{H}=0.5(\mathrm{~m})$

\begin{tabular}{|c|c|c|c|c|c|c|c|c|}
\hline № & $\begin{array}{c}\text { Sensor } \\
\text { №1 }(\mathrm{m})\end{array}$ & $\begin{array}{c}\text { Sensor } \\
\text { №2 }(\mathrm{m})\end{array}$ & $\begin{array}{c}\text { Sensor } \\
\text { №3 }(\mathrm{m})\end{array}$ & $\begin{array}{c}\text { Sensor } \\
\text { №4 }(\mathrm{m})\end{array}$ & K, \% & $\begin{array}{c}\text { Formula } \\
\text { O.Yu. Birskoy }\end{array}$ & $\begin{array}{c}\text { Formula } \\
\text { d'Angremond }\end{array}$ & $\begin{array}{c}\text { Formula } \\
\text { Briganti }\end{array}$ \\
\hline 1 & 2 & 3 & 4 & 5 & 6 & 7 & 8 & 9 \\
\hline 1 & 3.09 & 2.73 & 0.92 & 0.74 & 76.05 & 0.99 & 0.52 & 0.24 \\
\hline 2 & 2.93 & 2.74 & 0.80 & 0.69 & 76.45 & 0.90 & 0.50 & 0.23 \\
\hline 3 & 2.79 & 2.71 & 0.82 & 0.56 & 79.93 & 0.83 & 0.49 & 0.22 \\
\hline 4 & 2.77 & 2.39 & 0.96 & 0.56 & 79.78 & 0.82 & 0.49 & 0.22 \\
\hline 5 & 2.74 & 2.39 & 0.82 & 0.64 & 76.64 & 0.80 & 0.49 & 0.21 \\
\hline 6 & 2.71 & 2.26 & 0.53 & 0.53 & 80.44 & 0.79 & 0.48 & 0.21 \\
\hline 7 & 2.29 & 2.00 & 0.70 & 0.51 & 77.73 & 0.57 & 0.44 & 0.17 \\
\hline 8 & 2.26 & 2.05 & 0.80 & 0.51 & 77.43 & 0.55 & 0.44 & 0.17 \\
\hline 9 & 2.21 & 2.07 & 0.67 & 0.45 & 79.64 & 0.52 & 0.43 & 0.16 \\
\hline 10 & 2.18 & 1.81 & 0.67 & 0.48 & 77.98 & 0.51 & 0.43 & 0.16 \\
\hline 11 & 2.05 & 1.60 & 0.53 & 0.37 & 81.95 & 0.44 & 0.41 & 0.14 \\
\hline 12 & 2.00 & 1.65 & 0.56 & 0.43 & 78.50 & 0.41 & 0.41 & 0.14 \\
\hline 13 & 1.92 & 1.49 & 0.53 & 0.35 & 81.77 & 0.37 & 0.40 & 0.13 \\
\hline 14 & 1.86 & 1.41 & 0.53 & 0.37 & 80.11 & 0.34 & 0.39 & 0.12 \\
\hline 15 & 1.84 & 1.73 & 0.53 & 0.37 & 79.89 & 0.33 & 0.39 & 0.12 \\
\hline 16 & 1.73 & 1.68 & 0.40 & 0.35 & 79.77 & 0.27 & 0.37 & 0.10 \\
\hline 17 & 1.60 & 1.55 & 0.27 & 0.29 & 81.88 & 0.20 & 0.35 & 0.09 \\
\hline 18 & 1.46 & 1.30 & 0.40 & 0.27 & 81.51 & 0.13 & 0.32 & 0.06 \\
\hline 19 & 1.06 & 0.96 & 0.67 & 0.24 & 77.36 & -0.08 & 0.23 & -0.02 \\
\hline 20 & 1.01 & 0.88 & 0.27 & 0.21 & 79.21 & -0.11 & 0.21 & -0.03 \\
\hline 21 & 0.74 & 0.61 & 0.27 & 0.13 & 82.43 & -0.25 & 0.10 & -0.12 \\
\hline 22 & 0.72 & 0.64 & 0.27 & 0.13 & 81.94 & -0.26 & 0.09 & -0.13 \\
\hline 23 & 0.53 & 0.37 & 0.13 & 0.11 & 79.25 & -0.36 & -0.04 & -0.23 \\
\hline
\end{tabular}

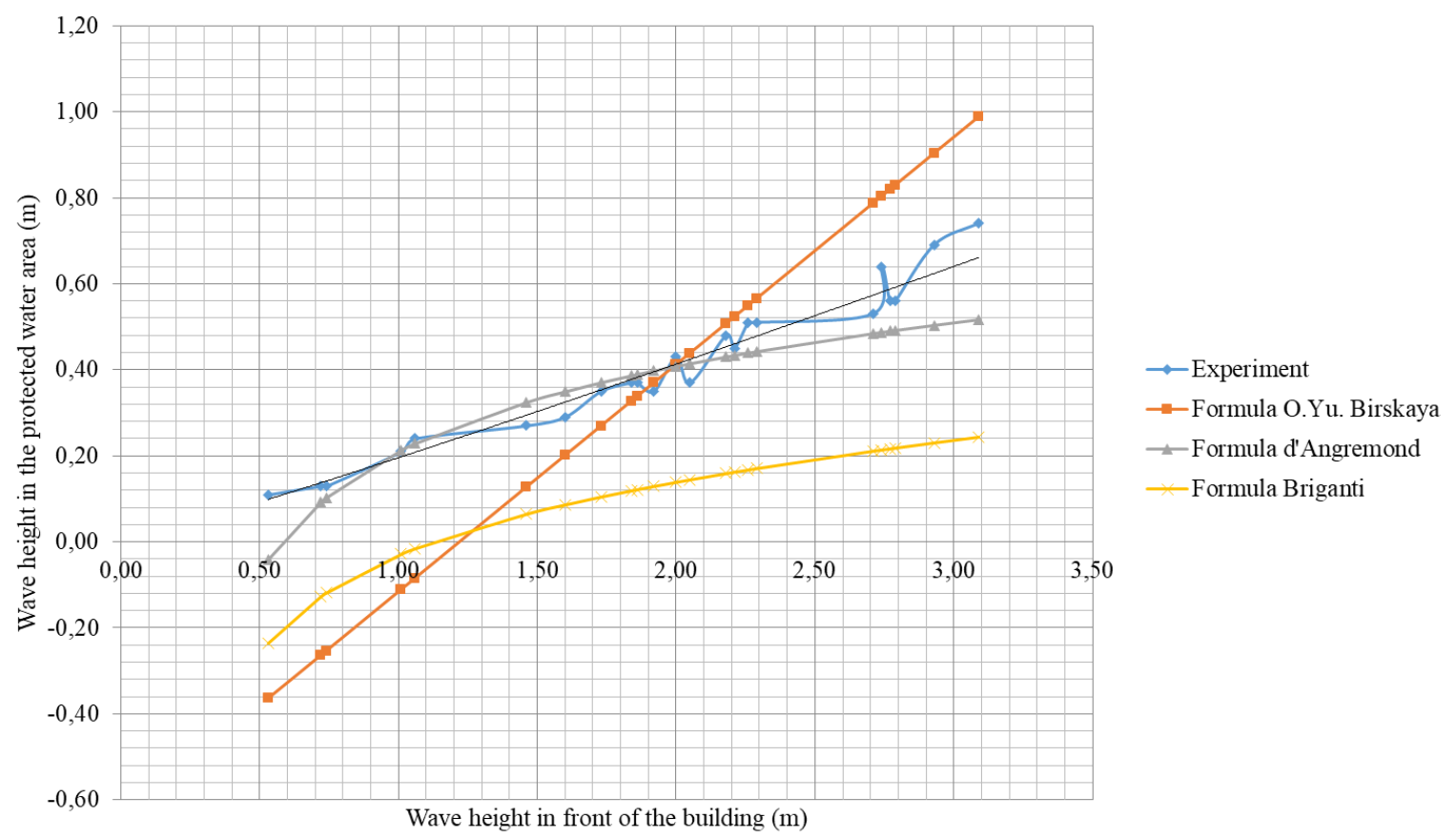

Fig. 4. Parameters of wave transformation at the width of the concrete massif $b=6.0(\mathrm{~m})$ and elevation $\Delta \mathrm{H}=0.5(\mathrm{~m})$ 
Table 3 - The results of experiments with the width of the concrete mass $b=6.0(\mathrm{~m})$ and elevation $\Delta \mathrm{H}=0(\mathrm{~m})$

\begin{tabular}{|c|c|c|c|c|c|c|c|c|}
\hline № & $\begin{array}{c}\text { Sensor } \\
\text { №1 }(\mathrm{m})\end{array}$ & $\begin{array}{c}\text { Sensor } \\
\text { №2 }(\mathrm{m})\end{array}$ & $\begin{array}{c}\text { Sensor } \\
\text { №3 }(\mathrm{m})\end{array}$ & $\begin{array}{c}\text { Sensor } \\
\text { №4 }(\mathrm{m})\end{array}$ & K, \% & $\begin{array}{c}\text { Formula } \\
\text { O.Yu. Birskoy }\end{array}$ & $\begin{array}{c}\text { Formula } \\
\text { d'Angremond }\end{array}$ & $\begin{array}{c}\text { Formula } \\
\text { Briganti }\end{array}$ \\
\hline 1 & 2 & 3 & 4 & 5 & 6 & 7 & 8 & 9 \\
\hline 1 & 2.53 & 1.62 & 1.09 & 1.04 & 58.89 & 0.93 & 0.50 & 0.22 \\
\hline 2 & 1.94 & 1.34 & 0.93 & 0.72 & 62.89 & 0.62 & 0.46 & 0.18 \\
\hline 3 & 1.65 & 1.08 & 0.93 & 0.68 & 58.79 & 0.46 & 0.44 & 0.17 \\
\hline 4 & 1.60 & 1.10 & 0.93 & 0.60 & 62.50 & 0.44 & 0.43 & 0.16 \\
\hline 5 & 1.46 & 0.98 & 0.53 & 0.50 & 65.75 & 0.36 & 0.42 & 0.15 \\
\hline 6 & 1.44 & 0.94 & 0.27 & 0.56 & 61.11 & 0.35 & 0.42 & 0.15 \\
\hline 7 & 1.41 & 0.96 & 1.06 & 0.64 & 54.61 & 0.34 & 0.42 & 0.15 \\
\hline 8 & 1.38 & 0.94 & 0.53 & 0.56 & 59.42 & 0.32 & 0.41 & 0.15 \\
\hline 9 & 1.33 & 0.92 & 0.67 & 0.56 & 57.89 & 0.30 & 0.41 & 0.14 \\
\hline 10 & 1.28 & 0.88 & 0.40 & 0.48 & 62.50 & 0.27 & 0.40 & 0.14 \\
\hline 11 & 1.17 & 0.84 & 0.53 & 0.48 & 58.97 & 0.21 & 0.39 & 0.13 \\
\hline 12 & 1.12 & 0.78 & 0.67 & 0.52 & 53.57 & 0.18 & 0.39 & 0.13 \\
\hline 13 & 1.09 & 0.82 & 0.53 & 0.46 & 57.80 & 0.17 & 0.39 & 0.13 \\
\hline 14 & 1.06 & 0.80 & 0.53 & 0.40 & 62.26 & 0.15 & 0.38 & 0.12 \\
\hline 15 & 1.04 & 1.82 & 0.67 & 0.44 & 57.69 & 0.14 & 0.38 & 0.12 \\
\hline 16 & 1.01 & 0.78 & 0.40 & 0.40 & 60.40 & 0.13 & 0.38 & 0.12 \\
\hline 17 & 0.98 & 0.80 & 0.40 & 0.44 & 55.10 & 0.11 & 0.37 & 0.12 \\
\hline 18 & 0.96 & 0.72 & 0.53 & 0.40 & 58.33 & 0.10 & 0.37 & 0.12 \\
\hline 19 & 0.80 & 0.70 & 0.53 & 0.42 & 47.50 & 0.02 & 0.35 & 0.10 \\
\hline 20 & 0.51 & 0.62 & 0.13 & 0.24 & 52.94 & -0.14 & 0.30 & 0.08 \\
\hline 21 & 0.45 & 0.40 & 0.27 & 0.20 & 55.56 & -0.17 & 0.29 & 0.07 \\
\hline 22 & 0.43 & 0.37 & 0.27 & 0.16 & 62.79 & -0.18 & 0.29 & 0.07 \\
\hline
\end{tabular}

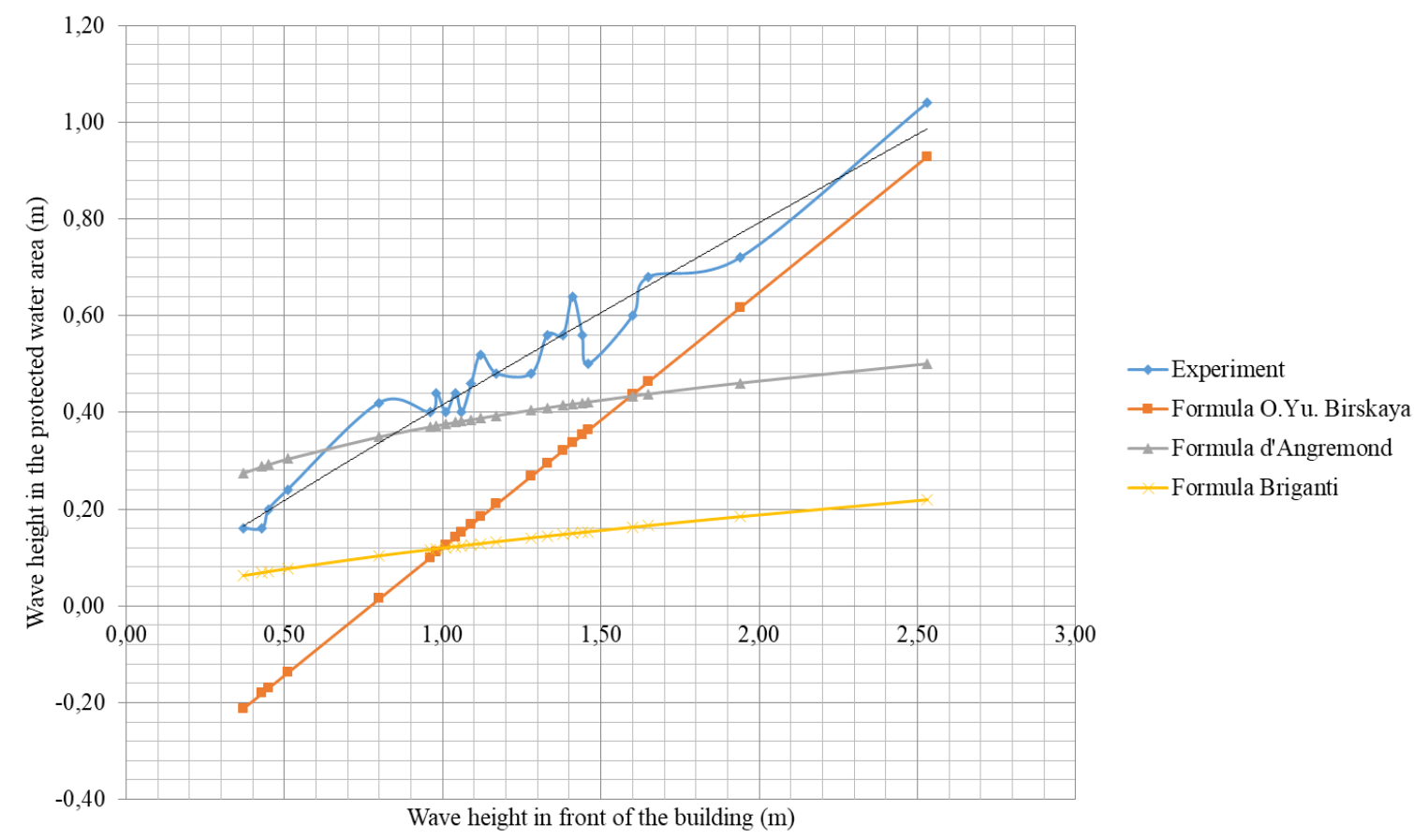

Fig. 5. Parameters of wave transformation at the width of the concrete massif $b=6.0(\mathrm{~m})$ and elevation $\Delta \mathrm{H}=0(\mathrm{~m})$ 
Conclusions. As a result of the performed experiments, the values of the change in the attenuation of the ox heights by the enclosing structure of the incomplete vertical profile were obtained in three computational cases. These cases differed in the location of the superstructure of the enclosure relative to the calculated water level. By comparing the damped wave heights obtained from the results of physical experiments and the existing methods of other authors, significant differences were found.

Underestimation of the mark of the surface structure of enclosing structures will lead to the fact that at the time of the calculated storm, there will be an overflow of the ridges of the wave heights of $1 \%$ security, through the upper structure of the structure to the protected port area. This circumstance will in no way create an emergency situation in the port or in the area of the coastal infrastructure of maritimecities. Underestimation of the mark of the superstructure of fencing structures will significantly reduce financial costs in the construction of new seaports, as well as in the repair of existing. This circumstance will in no way create an emergency situation; lowering the elevation of the ENS superstructure will reduce financial costs during construction by $10-15 \%$.

\section{References}

[1] O.Yu., Birskaya, G.D. Natal'chishin, "Issledovanie vozdeystviya razbivayushchikhsya voln na sooruzheniya nepolnogo vertikal'nogo profilya", Gidrotekhnicheskoe stroitel'stvo, no. 6, pp. 45-47, 1982.

[2] M.Sc. Thesis, R.P. van Oosten and J. Peixó Marco, Wave transmission at various types of low-crested structures using neural networks. 2005.

[3] CERC (US Army Coastal Engineering Research Centre). Shore Protection Manual, Washington, 1984.

[4] A. Koohestani, CRM-Change Management: The Role Of Training In Successful CRM Implementation. Masters thesis, Multimedia University. 2006.

[5] Recommendations of the Committee for Waterfront Structures Harbours and Waterways. EAU 1996, Ernst \&Sohn, Berlin, 2000.

[6] Nauchno-isledovatelskaya rabota «Raschotnoe obosnovanije i proektirovanije konstrukchiy gidrotechnicheskich soorujeniy dlja zashity ot zatopleniya morskimi volnami teritirii zavoda po adresy: Odessa, ul. Chernamorskogo Kazachestva, 72», OGASA, Odessa: 2016.

[7] V.A. Makarov, A.B. Menzin, Modelirovanie okeanologicheskikh protsessov (gidravlicheskoe $i$ analogovoe). Leningrad, 1979.

[8] L.I. Sedov, Metody podobiya i razmernosti v mekhanike. Moscow, Nauka Publ., 1977.

[9] P.G. Kiselev, Spravochnik po gidravlicheskim raschetam. Moscow, Ehnergiya Publ., 1972.

[10] L.S. Stolyarov, A.V. Chernetskiy, R.V. Sinitsa, "Opredelenie parametrov voln v laboratornykh usloviyakh pri pomoshchi sovremennoy izmeritel'noy apparatury", Visnik Odes'koï derzhavnoï akademï budivnictv ta arhitekturi, vol. 73, pp. 127-134, 2018.

[11] E.A. Lyubchenko, O.A. Chudnova, Planirovanie i organizatsiya ehksperimenta. Ch. 1. Vladivostok, TGEhU Publ., 2010. 


\title{
ЕКСПЕРИМЕНТАЛЬНІ ДОСЛІДЖЕННЯ ВПЛИВУ ХВИЛЬ НА ОГОРОДЖУВАЛЬНІ СПОРУДИ НЕПОВНОГО ВЕРТИКАЛЬНОГО ПРОФІЛЮ
}

\author{
Синиця Р.В., асистент, \\ sinitsa_roma@ukr.net, ORCID: 0000-0001-6796-4785 \\ Одеська державна академія будівництва та архітектури \\ вул. Дідріхсона, 4, м. Одеса, 65029, Україна
}

\begin{abstract}
Анотація. Стаття присвячена питанням фізичних експериментальних досліджень пов'язаних з визначенням параметрів гасіння хвиль при переливу їх через верхню будову огороджувальних гідротехнічних споруд (ОГТС) неповного вертикального профілю. Дослідження були проведені в гідрохвильовій лабораторії кафедри «Гідротехнічного будівництва» Одеської державної академії будівництва та архітектури. У статті представлені часткові результати експериментів, що проводились на ОГТС неповного вертикального профілю. Моделі були виконані в геометричному масштабі, які піддавалися хвильовим впливам аналогічним умовам натурної ділянки узбережжя Одеської затоки при дотриманні критеріїв подібності.
\end{abstract}

Будівництво нових конструкцій огороджувальних гідротехнічних споруд вимагають проведення ретельних первинних експериментальних досліджень. Дані дослідження найчастіше проводяться на фізичних моделях в спеціалізованих гідрохвильових лабораторіях, які дозволяють позбутися ризиків фінансових втрат при неправильному виборі типів і елементів проектованих об'єктів. Виконані дослідження дозволяють оцінювати 3 високим ступенем достовірності, у відповідності з масштабними умовами, фізику процесів, що протікають на моделях, які будуть також спостерігатися при експлуатації реальної споруди. Фізику процесу гідродинамічного впливу на гідротехнічні споруди найчастіше складно описати тільки за допомогою математичної моделі, що підтверджує високу ступінь важливості проведення фізичних експериментів.

Прогрес технічної науки в великій мірі залежить від можливості проведення більш точних вимірювань. При проведенні лабораторних досліджень була використана високоточна вимірювальна апаратура.

У даній роботі описана методика проведення експериментів, які були проведені на одній фізичній моделі, при трьох різних умовах розташування верхньої будови по відношенню до спокійного рівня, а також різних значеннях вихідних висот хвиль.

Застосування захисних споруд неповного вертикального профілю, з метою захисту акваторій морських портів, а також елементів берегової інфраструктури морських міст дозволить підвищити економічну привабливість за рахунок зниження фінансових витрат, завдяки зменшенню позначки надводної частини ОГТС.

Ключові слова: гідрохвильовий лоток, фізичне моделювання, огороджувальна гідротехнічна споруда неповного вертикального профілю. 


\title{
ЭКСПЕРИМЕНТАЛЬНЫЕ ИССЛЕДОВАНИЯ ВОЗДЕЙСТВИЯ ВОЛН НА ОГРАДИТЕЛЬНЫЕ СООРУЖЕНИЯ НЕПОЛНОГО ВЕРТИКАЛЬНОГО ПРОФИЛЯ
}

\author{
Синица Р.В., инженер, \\ sinitsa_roma@ukr.net, ORCID: 0000-0001-6796-4785 \\ Одесская государственная академия строительства и архитектуры \\ ул. Дидрихсона, 4, г. Одесса, 65029, Украина
}

\begin{abstract}
Аннотация. Статья посвящена вопросам физических экспериментальных исследований, связанных с определением параметров гашения волн при переливе их через верхнее строение оградительных гидротехнических сооружений (ОГТС) неполного вертикального профиля. Исследования были проведены в гидроволновой лаборатории кафедры «Гидротехническое строительство» Одесской государственной академии строительства и архитектуры. В статье представлены частичные результаты экспериментов, проводимых на ОГТС неполного вертикального профиля. Модели были выполнены в геометрическом масштабе, которые подвергались волновым воздействиям аналогичным условиям натурного участка побережья Одесского залива при соблюдении критериев подобия.

Строительство новых конструкций ограждающих гидротехнических сооружений требуют проведения тщательных первичных экспериментальных исследований. Данные исследования чаще всего проводятся на физических моделях в специализированных гидроволновых лабораториях, позволяют избавиться от рисков финансовых потерь при неправильном выборе типов и элементов проектируемых объектов. Осуществленные исследования позволяют оценивать с высокой степенью достоверности, в соответствии с масштабными условиями, физику процессов, протекающих на моделях, которые будут также наблюдаться при эксплуатации реального сооружения. Физику процесса гидродинамического воздействия на гидротехнические сооружения чаще всего сложно описать только с помощью математической модели, что подтверждает высокую степень важности проведения физических экспериментов.

Прогресс технической науки в большой степени зависит от возможности проведения более точных измерений. При проведении лабораторных исследований была использована высокоточная измерительная аппаратура.

В данной работе описана методика проведения экспериментов, которые были проведены на одной физической модели, при трех различных условиях расположения верхнего строения по отношению к спокойному уровню, а также различных значениях исходных высот волн.

Применение сооружений неполного вертикального профиля, с целью защиты акваторий морских портов, а также элементов береговой инфраструктуры морских городов позволит повысить экономическую привлекательность за счет снижения финансовых затрат, благодаря уменьшению отметки надводной части оградительных сооружений.

Ключевые слова: гидроволновой лоток, физическое моделирование, оградительное гидротехническое сооружение неполного вертикального профиля.
\end{abstract}

Стаття надійшла до редакції 17.06.2020 